\title{
AT-VESSEL FISHING MORTALITY FOR SIX SPECIES OF SHARKS CAUGHT IN THE NORTHWEST ATLANTIC AND GULF OF MEXICO
}

\author{
Alexia Morgan* and George H. Burgess \\ Florida Program for Shark Research, Florida Museum of Natural History, Dickinson Hall, \\ University of Florida, Museum Road, Gainesville, FL 32611 USA, *E-mail amorgan@flmnh. \\ ufl.edu
}

\begin{abstract}
From 1994-2005 the Commercial Shark Fishery Observer Program (CSFOP) placed fishery observers aboard US bottom longline vessels engaged in directed fishing for sharks in the region from New Jersey to Louisiana, USA. Observers routinely recorded species specific at-vessel mortality as related to enduring the stress of longline capture. Data for 5 species of sharks (sandbar Carcharhinus plumbeus, blacktip Carcharhinus limbatus, dusky Carcharhinus obscurus, tiger Galeocerdo cuvier, scalloped hammerhead Sphyrna lewini, and great hammerhead Sphyrna mokarran) were analyzed in this study. Multiple stepwise linear regressions indicate that age group, soak time and bottom water temperature can be used as predictors of at-vessel mortality and that size restrictions, size selective gear, restricting the soak time and time/area closures may be beneficial to fisheries targeting large coastal sharks.
\end{abstract}

\begin{abstract}
RESUMEN El Programa de Observación de la Pesquería Comercial de Tiburones sitúo observadores durante el periodo 1994-2005 en naves pesqueras dedicadas específicamente a la pesca con palangre de especies costeras grandes de tiburones en la región comprendida entre los estados de New Jersey y Lousiana en la costa estadounidense. Estos observadores tomaron datos sobre la habilidad de diferentes especies para sobrevivir el estrés de la captura con palangre. En este estudio analizamos datos de seis especies (Carcharhinus plumbeus o tiburón trozo, Carcharhinus limbatus o tiburón macuira, Carcharhinus obscurus o tiburón arenero, Galeocerdo cuvieri o tintorera tigre, Sphyrna lewini o cornuda común, y Sphyrna mokarran o cornuda gigante). El múltiplo el retroceso lineal progresivo indican que el uso de restricciones por tamaño, tiempo en el agua, tipo de equipo y el cierre de pesquerías por área o por periodo pueden beneficiar el manejo de las pesquerías de tiburones costeros grandes.
\end{abstract}

\section{INTRODUCTION}

Management of sharks in the western north Atlantic Ocean and Gulf of Mexico (GOM) waters of the United States has been politically, socially, economically and biologically contentious. For more than a decade, resource managers, fishery biologists and fishers have struggled to create a management plan that would allow sustainable fishing and economic viability for fishers. The exploitation of shark resources in this region has greatly increased over the past $2+$ decades (NMFS 1994, 1998, 2006). Stock assessment results have varied for individual species but generally conclude that shark mortality as a result of fishing (commercial and recreational) has exceeded the reproductive capacity of certain species to the detriment of overall stock size.

Sharks are susceptible to overfishing because of their K-selected life history characteristics (Heppell et al. 1999, Cortés 1999, 2002). Many species important to commercial and recreational fisheries grow slowly, have later ages of maturation, and a limited reproductive capacity. It has been estimated that several of the more important shark species in the fishery such as the sandbar (Carcharhinus plumbeus) (Sminkey 1994, Cortés 1999) and dusky (Carcharhinus obscurus) (Simpfendorfer 1999) sharks have a capacity to increase their population size at $<10 \%$ per year. Musick et al. (2000) noted that species with intrinsic rates of increase $<10 \%$ were particularly vulnerable to excessive mortalities and rapid population declines.

In addition, several species of shark commonly caught in the bottom longline shark fishery, including the dusky, great (Sphyrna mokarran) and scalloped hammerheads (Sphyrna lewini), suffer from very high at-vessel fishing mortality rates (Morgan and Burgess unpublished data, University of Florida, Gainesville, FL). At-vessel fishing mortality pertains to whether individual sharks are alive or dead when brought on board the vessel (i.e., death results directly from the in-water fishing process). An individual shark species' at-vessel fishing mortality rate has a large impact on the success or failure of management plans designed to protect it. Management techniques such as quotas and prohibited species are based on the assumption that individuals of regulated species are returned to the sea alive. This assumption is erroneous if the regulated species has high at-vessel fishing mortality.

Although sharks historically have been managed as groups (large coastal, small coastal, pelagic, prohibited and dogfish; NMFS 1999), future management of sharks in the northwest Atlantic and GOM will likely be species specific. Therefore, we analyzed our at-vessel mortality data set for information on species specific viability as related to enduring the stress of longline capture. Sandbar, black- 


\section{MORGAN AND BuRGESS}

tip (Carcharhinus limbatus), dusky, tiger (Galeocerdo cuvier), scalloped hammerhead, and great hammerhead sharks were analyzed to determine if there was a difference in at-vessel mortality rates between species, gender, age groups, longline fishing soak times and bottom water temperature. These species represent one prohibited species (dusky), the 4 most commonly caught large coastal species in the fishery, and the great hammerhead (large coastal). This latter species is of particular interest due to its high at-vessel mortality and that it mirrors that of the abundant scalloped hammerhead (Morgan and Burgess unpublished data, University of Florida, Gainesville, FL).

\section{MeThodS}

The Commercial Shark Fishery Observer Program (CSFOP) placed trained fishery observers aboard commercial bottom longline vessels targeting sharks from New Jersey to Louisiana from January 1994 to April 2005. Fishing vessels primarily deployed heavy-duty monofilament mainlines ranging in length from $1.9-44.5 \mathrm{~km}$, with 53-2,835 hooks attached to the ends of 1.8-2.4 m gangions. Hooks ranged in size from $3 / 0$ to $20 / 0$ and primarily consisted of circle hooks, although some "J" hooks were employed. The mainline was anchored to the bottom using weights during the setting of the gear and gangions were set at or near the bottom. Gear typically was set at sunset and hauled back the following morning near dawn.

Fishery observers were trained in species identification and data collection prior to deployment. Observers collected catch and effort data from each longline set targeting sharks. Fishing gear configuration used during individual bottom longline sets was documented prior to the start of each set. The times when the first and last hooks entered and were removed from the water were recorded by the observer during the setting and retrieval of the gear. Soak time (hr) is defined as the interval between the time the first hook entered the water until the first hook was removed from the water. The bottom water temperature ( ${ }^{\circ} \mathrm{C}$ ) was recorded by a Stowaway XTI temperature/depth recorder (Onset Computer Corporation) attached to the mainline during the set and subsequently downloaded onto a laboratory computer. Individual caught sharks were brought on board the vessel and identified to species, measured (cm FL), sexed and condition noted as alive/dead. Data was archived at the Florida Museum of Natural History were prior to analysis.

Data from 8,583 sandbar, 1,982 blacktip, 2,466 tiger, 662 dusky, 455 scalloped hammerhead, and 178 great hammerhead sharks were analyzed in this study. This subset was utilized because there was not corresponding data on the soak time and/or bottom water temperature on all sets made during the study period. Data was analyzed by gender (female and male) and 3 FLs derived age groups (age-0, juvenile and adult). The sandbar was considered age-0 at FLs from 0-60 cm, juvenile from 61-150 cm and adult at $>150 \mathrm{~cm}$ (Mearson and Pratt 2001). Blacktips were considered age- 0 at FLs from $0-75 \mathrm{~cm}$, juvenile from $75-115 \mathrm{~cm}$ and adult at $>115 \mathrm{~cm}$ (Carlson et al. 2006). Tigers were considered age-0 at FLs from 0-06 cm, juvenile from $107-257 \mathrm{~cm}$ and adult at $>258 \mathrm{~cm}$ (Natanson et al. 1999). Duskies were considered age-0 at FLs from 0-100 cm, juvenile from $101-231 \mathrm{~cm}$ and adult at $>231$ $\mathrm{cm}$ (Natanson et al. 1994). Scalloped hammerheads were considered age-0 at FLs from 0-65 cm, juvenile from 66-137 $\mathrm{cm}$ and adult at $>137 \mathrm{~cm}$ (Branstetter 1987). Great hammerheads were considered age-0 at FLs from $0-80 \mathrm{~cm}$, juvenile from 101-189 cm and adult at $>190 \mathrm{~cm}$ (Castro 1983, Stevens and Lyle 1989). Soak times were broken into six 4-hr bins (0-4 hr, 5-8 hr, 9-12 hr, 13-16 hr, 17-20 $\mathrm{hr}$ and $>20 \mathrm{hr}$ ) and bottom water temperature was broken into six $5^{\circ}$ bins $\left(0-10^{\circ} \mathrm{C}, 11-15^{\circ} \mathrm{C}, 16-20^{\circ} \mathrm{C}, 21-25^{\circ} \mathrm{C}\right.$, $26-30^{\circ} \mathrm{C}$ and $\left.>30^{\circ} \mathrm{C}\right)$. Mortality for each species was calculated by dividing the total number of dead sharks caught by the total number of sharks caught by gender, soak time, age group and bottom water temperature category.

We performed a multiple stepwise linear regression for each individual species, using mortality as the dependent variable and gender, soak time, age group and bottom water temperature as independent variables. Variables had to be significant at $P<0.15$ before they could be entered into the model and had to be significant at $P<0.10$ to remain in the model (Murphy et al. 1995). Species (1-6) and gender $(1=$ female and $0=$ male $)$ were coded with dummy variables. Median values were used for soak time bins, bottom water temperature bins and age groups. The proportion of dead animals (for each gender, age group, soak time bin and bottom water temperature bin) by species were arcsine transformed (prior to regression analysis) to meet the assumption of normality (Diaz and Serafy 2005). All other assumptions of multiple linear regressions (linearity, $\mathrm{X}$ is measured without error, homoscedasticity, independent variables and random sampling) were met. All analyses were performed using SAS 9.1 (SAS Institute, Cary, NC).

\section{RESUlt}

Sharks ranged in FLs from 54-214 cm for the sandbar, $59-165 \mathrm{~cm}$ for the blacktip, $53-318 \mathrm{~cm}$ for the tiger, 61-289 $\mathrm{cm}$ for the dusky, $56-287 \mathrm{~cm}$ for the scalloped hammerhead, and $78-330 \mathrm{~cm}$ for the great hammerhead 
sharks. The tiger shark had the lowest overall at-vessel mortality rate $(8.5 \%$ total, $9.1 \%$ young, $7.6 \%$ juvenile, and $37.5 \%$ adult), followed by the sandbar (36.1\% total, $89.1 \%$ young, $41.8 \%$ juvenile, and $22.4 \%$ adult), dusky (81.1\% total, $87.7 \%$ young, $82.4 \%$ juvenile, and $44.4 \%$ adult), blacktip ( $88 \%$ total, $86.4 \%$ young, $90.5 \%$ juvenile and $87.3 \%$ adult), scalloped hammerhead (91.4\% total, $70 \%$ young, $95.2 \%$ juvenile and $90.9 \%$ adult) and great hammerhead $(93.8 \%$ total, $86.4 \%$ young, $90.5 \%$ juvenile and $87.3 \%$ adult) (Table 1 ).

The regression model including soak time, bottom water temperature and age group explained $46 \%$ (adjusted $\mathrm{R}^{2}$ ) of the variation in mortality for the blacktip shark $(\mathrm{F}=9.9, P<0.0001)$ (Table 2). Soak time and bottom water temperature had a positive effect on mortality indicating that increases in soak time and bottom water temperature (by one unit effort) would increase mortality while size had a negative effect on mortality indicating that increases in size (by one unit effort) would decrease mortality, when all other variables are held constant (Table 2).

Soak time and bottom water temperature were included in the final model for the tiger $(\mathrm{F}=6.7, P=0.003)$, dusky $(\mathrm{F}=6.5, P=0.007)$ and great hammerhead $(\mathrm{F}=10.8$, $P=0.0003$ ) sharks (Table 2). These models explain 23\%, $32 \%$ and $39 \%$ of the variation in mortality respectively (Table 2). Soak time had a positive effect on mortality for all 3 species and bottom water temperature had a positive effect on mortality for the dusky shark but a negative effect on mortality for the tiger and great hammerhead sharks (Table 2).

The sandbar shark's final model included the variables soak time and age group $(\mathrm{F}=19.2, P=0.0001)$ and explained $44 \%$ of the variation in mortality (Table 2). Soak time had a positive effect and size had a negative effect on mortality (Table 2).

The final model for the scalloped hammerhead included the variable soak time $(\mathrm{F}=9.1, P=0.006)$ and explained $24 \%$ of the variation in mortality rates for this species. Soak time had a positive effect on mortality (Table 2).

\section{Discussion}

Gender does not factor into at-vessel mortality rates but age group, soak time, and bottom water temperature are important predictors of mortality. Studies have shown that size, soak time (Diaz and Serafy 2005) and water temperature (Manire et al. 2001) could affect mortality rates and earlier interim analyses of our data (Burgess and Morgan 2005) have provided evidence of speciesspecific at-vessel mortality rates. Existing management of sharks in Atlantic waters of the United States has failed to adequately protect certain species (Cortés et al. 2002, NMFS 2006b) and future management will likely require alternative management tools, such as time/area closures, size limits, and gear modifications (i.e., size-selective gear and reducing the soak time of the fishing gear). The results from this study will give fisheries managers better insight into which factors affect at-vessel mortality for commercially important shark species and which alternative management plans may be most effective.

Size has been shown to be an important component of mortality in various species (Davis 2002). Diaz and Serafy (2005) showed the proportion of blue sharks (Prionace glauca) caught on longline gear and returned to sea alive increased with size. Mortality of longline-caught Atlantic cod (Gadus morhua) was highest at small sizes (Milliken et al. 1999) and small haddock (Melanogrammus aeglefinus) and whiting (Merlangius merlangus) caught in trawls had the highest discard mortality rates (Sangster et al. 1996). Our data similarly reveal that at-vessel mortality rates decrease as size increases for sandbar and blacktip sharks. In contrast, great hammerhead and scalloped hammerhead sharks suffered very high at-vessel mortality in all age groups.

The increased physiological stresses caused by capture makes it more difficult for smaller animals to survive the fishing process (Davis 2002). Demographic analysis has shown that changes in juvenile sharks' survival (Heppell et al.1999, Cortés 2002) has the greatest effect on overall population growth rates. Fisheries managers could use size limits to protect certain age groups from at-vessel mortality rates. Sandbar sharks likely can benefit from size restrictions aimed at protecting the juvenile and young age groups. However, species which suffer from high at-vessel mortality rates in all size classes (great hammerhead, scalloped hammerhead) would not benefit from size limits.

Soak time is an important factor because many carcharhinid and sphyrnid sharks are considered obligate ram ventilators (Carlson et al. 2004), relying on constant movement to force oxygenated water over their gills. The great and scalloped hammerheads (Carlson et al. 2004), blacktip (Manier et al. 2001) and likely the dusky shark are active epibenthic species that are considered obligate ram ventilators, making them more likely to be affected by longer soak times than slower swimming ground sharks. Sharks that rely on ram ventilation must increase either swimming speed and/or mouth gape in order to compensate for decreases in oxygen availability (Carlson and Parsons 2001). It would be very difficult for these species to increase their swimming speed while hooked on a longline, resulting in relatively rapid asphyxiation following hooking. The sandbar shark, a species closely 
MoRgAn AND BuRgesS

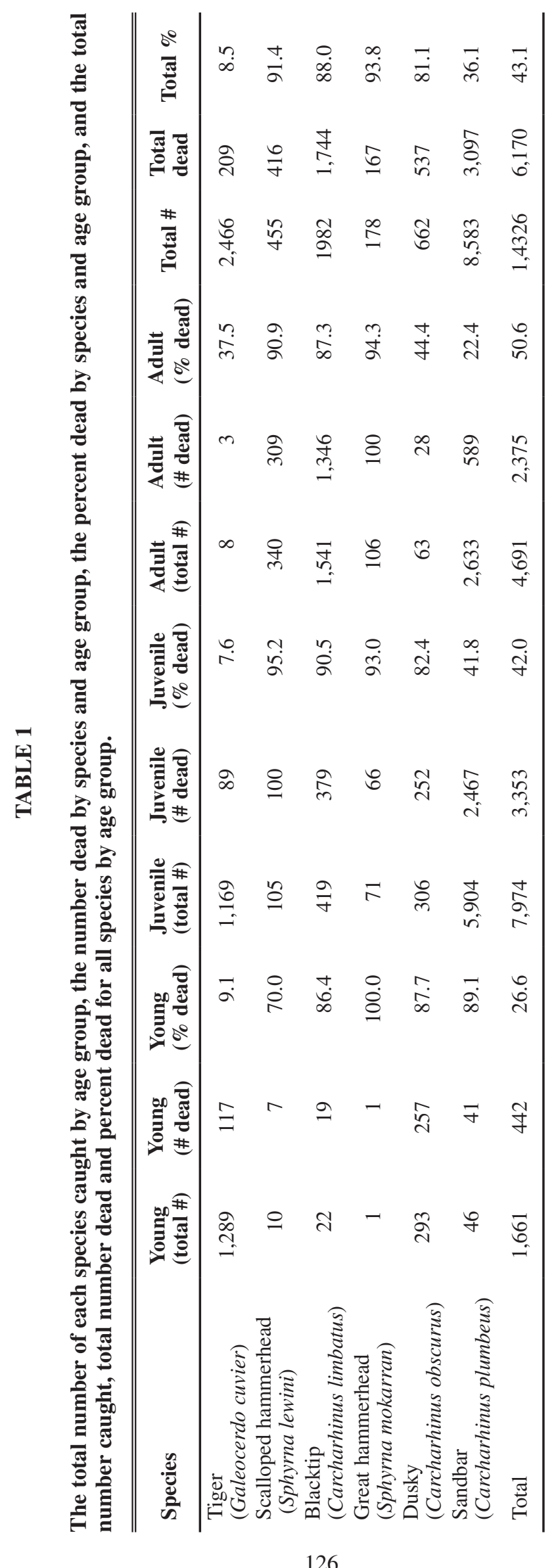


TABLE 2

Summary results for multiple stepwise linear regressions for each species, including adjusted $\mathbf{R}^{2}$, final variables, degrees of freedom (DF), parameter estimates, standard error $\left(\mathrm{s}_{\bar{x}}\right)$, $t$ value and $\boldsymbol{P}$ value.

\begin{tabular}{|c|c|c|c|c|c|c|}
\hline \multicolumn{7}{|c|}{ "Tiger (Galeocerdo Cuvier) $(\mathrm{F}=6.7, P=0.003)$} \\
\hline \multirow[t]{4}{*}{$\mathrm{R}^{2}=0.23$} & Variable & DF & $\begin{array}{l}\text { Parameter } \\
\text { estimate }\end{array}$ & $\mathrm{s}_{\overline{\mathrm{x}}}$ & $\mathrm{t}$ value & $P$ value \\
\hline & Intercept & 1 & 0.51 & 0.23 & 2.3 & 0.030 \\
\hline & Soak time & 1 & 0.02 & 0.01 & 1.9 & 0.072 \\
\hline & Bottom water temperature & 1 & -0.02 & 0.01 & -3.0 & 0.006 \\
\hline \multicolumn{7}{|c|}{ Scalloped hammerhead (Sphyrna lewini) $(\mathrm{F}=9.1, P=0.006)$} \\
\hline \multirow[t]{2}{*}{$\mathrm{R}^{2}=0.24$} & Intercept & 1 & 1.01 & 0.16 & 6.4 & $<0.0001$ \\
\hline & Soak time & 1 & 0.03 & 0.01 & 3.0 & 0.006 \\
\hline \multicolumn{7}{|c|}{ Blacktip (Carcharhinus limbatus) $(\mathrm{F}=9.9, P<0.0001)$} \\
\hline \multirow[t]{4}{*}{$\mathrm{R}^{2}=0.46$} & Intercept & 1 & -0.02 & 0.41 & -0.6 & 0.950 \\
\hline & Soak time & 1 & 0.06 & 0.01 & 4.8 & $<0.0001$ \\
\hline & Bottom water temperature & 1 & 0.04 & 0.01 & 2.9 & 0.007 \\
\hline & Age group & 1 & -0.17 & 0.08 & -2.0 & 0.055 \\
\hline \multicolumn{7}{|c|}{ Dusky (Carcharhinus obscurus) $(\mathrm{F}=6.5, P=0.007)$} \\
\hline \multirow[t]{3}{*}{$\mathrm{R}^{2}=0.32$} & Intercept & 1 & -0.40 & 0.50 & -0.8 & 0.400 \\
\hline & Soak time & 1 & 0.04 & 0.02 & 2.0 & 0.060 \\
\hline & Bottom water temperature & 1 & 0.06 & 0.02 & 2.0 & 0.006 \\
\hline \multicolumn{7}{|c|}{ Great hammerhead (Sphyrna mokarran) $(\mathrm{F}=10.8, P=0.0003)$} \\
\hline \multirow[t]{3}{*}{$\mathrm{R}^{2}=0.39$} & Intercept & 1 & 0.62 & 0.40 & 1.6 & 0.120 \\
\hline & Soak time & 1 & 0.07 & 0.02 & 4.0 & 0.0004 \\
\hline & Bottom water temperature & 1 & -0.03 & 0.02 & -2.1 & 0.050 \\
\hline \multicolumn{7}{|c|}{ Sandbar $($ Carcharhinus plumbeus $)(\mathrm{F}=19.2, P<0.0001)$} \\
\hline \multirow[t]{3}{*}{$\mathrm{R}^{2}=0.44$} & Intercept & 1 & 0.60 & 0.21 & 2.8 & 0.008 \\
\hline & Soak time & 1 & 0.04 & 0.01 & 5.0 & $<0.0001$ \\
\hline & Age group & 1 & -0.24 & 0.07 & -3.0 & 0.002 \\
\hline
\end{tabular}

associated with substrate (Compagno 1984), is also an obligate ram ventilator (Dowd et al. 2006) but does not suffer from a very high at-vessel mortality rate. The sandbar's association with oxygen-poor epibenthic waters and slower ambient swimming speed (inferred from it stocky body), apparently make this species better suited to survival when swimming is confined after being hooked on a longline. The tiger shark, another slow swimmer that makes frequent forays into benthic waters (Compagno 1984), is most likely able to compensate while hooked on a longline, by increasing its mouth gape and using a buccal pump system to force water over its larger mouth.

Fisheries managers may consider putting restrictions on the length of soak time in order to better protect species which rely on obligate ram ventilation and suffer from very high at-vessel mortality rates. That said, soak time only reveals how long the total gear was in the water but gives no indication of how long individual sharks were hooked on the individual gangions. Our ongoing studies employing hook timers (Boggs 1992) should provide useful information to more accurately characterize the importance of soak time.

Increases in water temperature have been shown to have a negative effect on sharks' survival (Manire et al. 2001) and can lead to acidosis (Heisler 1998). Atlantic salmon (Salmo salar) have been shown to suffer higher post release mortality when caught in water $>20^{\circ} \mathrm{C}$ (Wilkie et al. 1996). The warmer water temperature combined with increased activity while hooked, lead to the salmon's inability to fully recover. Species of shark with 


\section{MORGAN AND BuRgESS}

the physiological abilities to endure levels of hypoxia and acidosis will fare the best in water temperatures outside their natural range (Carlson et al. 2003). It is possible that individual shark species' behavior when hooked will also affect their ability to survive in different bottom water temperatures. Species that fight while hooked will use more oxygen, which could lead to increased physiological stress and possible death. Fisheries managers could restrict fishing to certain times of year through the use of time/area closures to offset the effects of water temperature on atvessel mortality.

Future studies should determine how long the sharks are hooked on the longline, ascertain if the length of the gangion has any affect on at-vessel mortality, determine whether the type of hook (i.e., circle or "J") or size of hook affects at-vessel mortality, establish relationships between water temperature, physiological stress and at-vessel mortality for individual species and determine if the behavior of the sharks when hooked affects mortality. Our study gives an understanding of some aspects of bottom longline fishing, which affect at-vessel mortality, but there are still a number of factors that should be looked at in order to provide a full understanding of this type of mortality.

\section{ACKNOWLEDGMENTS}

We would like to thank all of the fisheries observers and vessel captains who enabled the collection of all data used in this paper. Funding was provided by the National Marine Fisheries Service, Marine Research and Fisheries Initiative Program (MARFIN) and the Saltsonstall Kennedy programs.

\section{Literature Cited}

Boggs, C.H. 1992. Depth, capture time, and hooked longevity of longline-caught pelagic fish: Timing bites of fish with chips. Fishery Bulletin 90:643-658.

Branstetter, S. 1987. Age, growth and reproductive biology of the silky shark, Carcharhinus falciformis, and the scalloped hammerhead, Sphyrna lewini, from the northwestern Gulf of Mexico. Environmental Biology of Fishes 19:161-173.

Burgess, G.H. and A. Morgan. 2005. Commercial Shark Fishery Observer Program: Monitoring the directed bottom longline shark fishery in the Atlantic Ocean and Gulf of Mexico off the mid and southeastern United States, 2005 fishing season 1. National Marine Fisheries Service Final Report. Florida Museum of Natural History, Gainesville, FL, USA, 34 p.

Carlson, J.K. and G.R. Parsons. 2001. The effects of hypoxia on 3 sympatric shark species: physiological and behavioral responses. Environmental Biology of Fishes 61:427-433.
Carlson, J. K., K.J. Goldman, and C.G. Lowe. 2004. Metabolism, energetic demand, and endothermy. In: J.C. Carrier, J.A. Musick, and M.R. Heithaus, eds. Biology of Sharks and Their Relatives. CRC Press, Boca Raton, FL, USA, p. 203-224.

Carlson, J.K., J.R. Sulikowski, and I.E. Baremore. 2006. Do differences in life history exist for blacktip sharks, Carcharhinus limbatus, from the United States South Atlantic Bight and Eastern Gulf of Mexico? Environmental Biology of Fishes 77:273-277.

Castro, J.I. 1993. The Sharks of North American Waters. Texas A\&M University Press, College Station, TX, USA, 55 p.

Compagno, L.J.V. 1984. FAO species catalogue, Vol. 4. Sharks of the world. Part 2-Carcharhiniformes. FAO Fisheries Symposium 4:250-655.

Cortés, E. 1999. A stochastic stage-based population model of the sandbar shark in the western north Atlantic. American Fisheries Society Symposium 23:115-136.

Cortés, E. 2002. Incorporating uncertainty into demographic modeling: Application to shark populations and their conservation. Conservation Biology 16:1048-1062.

Cortés, E., L. Brooks, and G. Scott. 2002. Stock Assessment of large coastal sharks in the U.S. Atlantic and Gulf of Mexico. NMFS Sustainable Fisheries Division Contribution SFD02/03-177. National Marine Fisheries Service, Southeast Fisheries Science Center, Panama City, FL, USA 61 p.

Davis, M. 2002. Key principles for understanding fish bycatch discard mortality. Canadian Journal of Fisheries and Aquatic Sciences 59:1834-1843.

Diaz, G.A. and J.E. Serafy. 2005. Longline-caught blue shark (Prionace glauca): Factors affecting the numbers available for live release. Fishery Bulletin 103:720-724.

Dowd, W.W., R.W. Brill, P.G. Bushnell, and J.A. Musick. 2006. Standard and routine metabolic rates of juvenile sandbar sharks (Carcharhinus plumbeus) including the effects of body mass and acute temperature change. Fisheries Bulletin 104:323-331.

Heppell, S.S., L.B. Crowder, and T.R. Menzel. 1999. Life table analysis of long lived marine species with implications for conservation and management. In: J.A. Musick, ed. Life in the Slow Lane; Ecology and conservation of long-lived marine animals. American Fisheries Society, Bethesda, MD, USA, p. 137-148.

Heisler, N. 1998. Acid-base regulation. In: T.J. Shuttleworth, ed. Physiology of elasmobranch fishes. Springer-Verlag, Berlin, Germany, p. 215-252.

Manire C., R. Hueter, E. Hull, and R. Spieler. 2001. Serological changes associated with gill-net capture and restraint in 3 species of sharks. Transactions of the America Fisheries Society 130:1038-1048.

Mearson R.R. and H.L. Pratt Jr. 2001. Distribution, movements and growth of young sandbar sharks, Carcharhinus plumbe$u s$, in the nursery ground of Delaware Bay. Environmental Biology of Fishes 61:13-24.

Milliken, H.O, M. Farrington, H.A. Carr, and E. Lent. 1999. Survival of Atlantic cod (Gadus morhua) in the Northwestern Atlantic longline fishery. Marine Technological Society Journal 33:19-24. 


\section{At-Vessel Shark Mortality in North Atlantic}

Murphy, M.D., R.F. Heagey, V.H. Neugebauer, M.D. Gordon, and J.L. Hintz. Mortality of spotted seatrout released from gill-net or hook-and-line gear in Florida. North American Journal of Fisheries Management 15:748-753.

Musick. J.A., M.M. Harbin, S.A. Berkeley, G.H. Burgess, A.M. Eklund, L. Findley, R.G. Gilmore, J.T. Golden, D.S. Ha, G.R. Huntsman, J.C. McGovern, G.R. Sedberry, S.J. Parker, S.G. Poss, E. Sala, T.W. Schmidt, H. Weeks, and S.G. Wright. 2000. Marine, estuarine and diadromous fish stocks at risk of extinction in North America (Exclusive of Pacific salmonids). Fisheries 25:6-30

Natanson, L.J., J.G. Casey, and N.E. Kohler. 1994. Age and growth estimates for the dusky shark, Carcharhinus obscurus, in the Western North Atlantic Ocean. Fishery Bulletin 93:116-126.

Natanson, L.J, J.G. Casey, and N.E. Kohler. 1999. Growth of the tiger shark, Galeocerdo cuvier, in the western North Atlantic based on tag returns and length frequencies; and a note on the effects of tagging. Fishery Bulletin 97:944-953.

National Marine Fisheries Service. 1994. Report of the shark evaluation workshop. NMFS Report. National Marine Fisheries Service, Southeast Fisheries Science Center, Miami, FL, USA, $17 \mathrm{p}$.

National Marine Fisheries Service. 1999. Fishery management plan for Atlantic tunas, swordfish and sharks. National Marine Fisheries Report. Office of Sustainable Fisheries, Highly Migratory Species Division, Silver Spring, MD, USA, $97 \mathrm{p}$.

National Marine Fisheries Service. 2006a. Final consolidated Atlantic Highly Migratory Species Fishery Management Plan. National Marine Fisheries Report. National Marine Fisheries Service. Silver Spring, MD, USA, 579 p.
National Marine Fisheries Service. 2006b. SEDAR 11 stock assessment report: Large coastal shark complex, blacktip and sandbar shark. National Marine Fisheries Report. National Marine Fisheries Service, Silver Spring, MD, USA, $387 \mathrm{p}$.

Sangster, G.I., K. Lehmann, and M. Breen. 1996. Commercial fishing experiments to assess the survival of haddock and whiting after escape from four sizes of diamond mesh codends. Fisheries Research 25:323-345.

Simpfendorfer, C.A. 1999. Demographic analysis of the dusky shark fishery in southwestern Australia. In: J.A. Musick, ed. Life in the Slow Lane; Ecology and conservation of longlived marine animals. American Fisheries Society, Bethesda, MD, USA, p. 149-160.

Sminkey, T.R. 1994. Demographic analysis of the sandbar shark, Carcharhinus plumbeus, in the north Atlantic. Fishery Bulletin 94:341-347.

Stevens J.D. and J.M. Lyle. 1989. Biology of three hammerhead sharks (Eusphyra blochii, Sphyrna mokarran and S. lewini) from Northern Australia. Australian Journal of Freshwater Research 40:129-146.

Wilkie. M.P., K. Davidson, M.A. Brobbel, J.D. Kieffer, R.K. Booth, A.T. Bielak, and B.L. Tufts.1996. Physiology and survival of wild Atlantic salmon following angling in warm summer waters. Transactions of the American Fisheries Society 125:572-580. 